Portland State University

PDXScholar

8-4-1992

\title{
Assessment: Authentic Strategies for Early Childhood Education
}

Gail Ann Hathaway Tupper

Portland State University

Follow this and additional works at: https://pdxscholar.library.pdx.edu/open_access_etds

Part of the Curriculum and Instruction Commons

Let us know how access to this document benefits you.

\section{Recommended Citation}

Tupper, Gail Ann Hathaway, "Assessment: Authentic Strategies for Early Childhood Education" (1992). Dissertations and Theses. Paper 4565.

https://doi.org/10.15760/etd.6449

This Thesis is brought to you for free and open access. It has been accepted for inclusion in Dissertations and Theses by an authorized administrator of PDXScholar. Please contact us if we can make this document more accessible: pdxscholar@pdx.edu. 
AN ABSTRACT OF THE THESIS OF Gail Ann Hathaway Tupper for the Master of Science in Education: Curriculum and Instruction presented August 4, 1992 .

Title: Assessment: Authentic Strategies for Early Childhood Education.

APPROVED BY MEMBERS OF THE THESIS COMMITTEE:
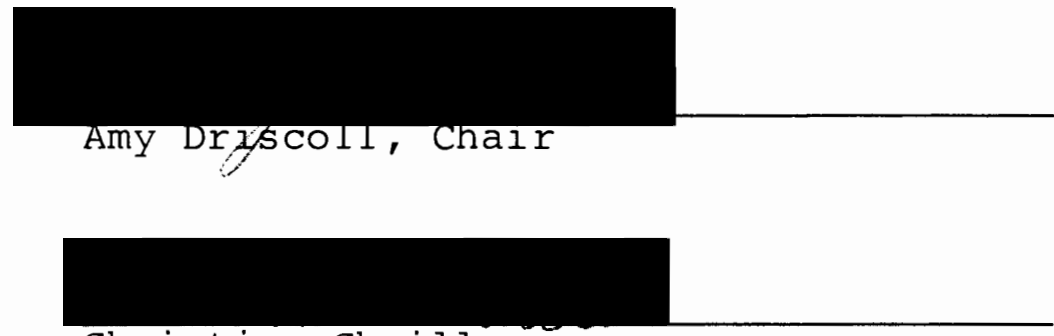

Christine Chaille

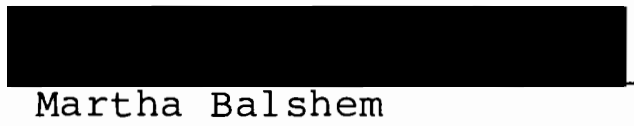

This thesis explores the relationship between assessment techniques and reporting procedures in early childhood settings. Discrepancies between curriculum being presented and skills and progress being reported are examined.

The curriculum used in this study is Portland Public Schools' Piaget Curriculum, which stresses active, scientific problem solving for children 4 to 6 years old. 
A variety of assessment, observation, recording and reporting tools are suggested, implemented and critiqued. Creation of a portfolio to store and showcase these items is suggested and explained.

The important role of parents and families in the assessment process is studied. Strategies for involving parents at all stages of implementation are included and field tested.

The result is a unique, lively, complete look at the teacher's efforts to use authentic assessment strategies which honestly match the curriculum unfolding in the classroom. 


\title{
ASSESSMENT: AUTHENTIC STRATEGIES FOR EARLY CHILDHOOD EDUCATION
}

\author{
by
}

GAIL ANN HATHAWAY TUPPER

\section{A thesis submitted in partial fulfillment of the requirements for the degree of \\ MASTER OF SCIENCE \\ in \\ EDUCATION: CURRICULUM AND INSTRUCTION}

$$
\begin{aligned}
& \text { Portland State University } \\
& 1992
\end{aligned}
$$


TO THE OFFICE OF GRADUATE STUDIES:

The members of the Committee approve the thesis of Gail Ann Hathaway Tupper presented August 4, 1992 .

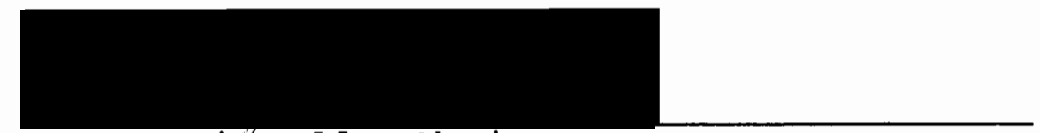
Amy Driscoll, Chair

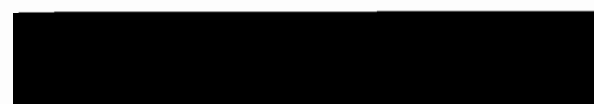

Christine Chaille

\section{Martha Balshem}

APPROVED :
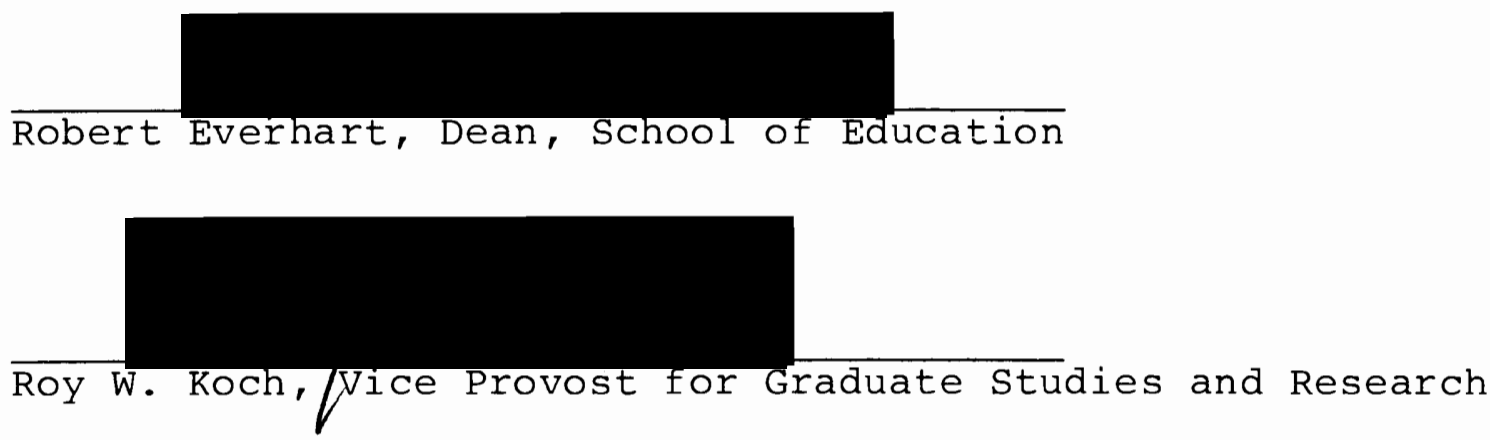
TABLE OF CONTENTS

PAGE

INTRODUCTION: SCENARIO OF REALITY . . . . . . . . . . I 1

Behind the Scenario............. . 1

Potential for Alternatives . . . . . . . . 3

PORTFOLIOS AS AN EFFECTIVE ASSESSMENT VEHICLE • • • • 6

DEVELOPMENT OF DEVELOPMENTALLY APPROPRIATE

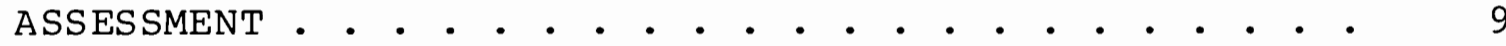

Observation: A Worthwhile Technique . . . . . 9

Spontaneous vs. Planned Observation . . . . . 11

THE VISIBLE CURRICULUM . . . . . . . . . . . . 13

THE HIDDEN CURRICULUM: SOCIAL LIFE IN

THE CLASSROOM . . . . . . . . . . . . . . . . 19

What Can Be Learned When the Teacher

Steps Back? ............... 20

What Is There to Be Learned? . . . . . . . . 21

How Can Data Be Collected? . . . . . . . . 23

Seeking the Hidden Curriculum . . . . . . . 25

THE EXTRA-CURRICULAR CURRICULUM: SHARING

ASSESSMENT WITH FAMILIES . . . . . . . . . . . . 31

Sharing Assessment with Families:

The Components........... . 32

CONCLUSION: SCENARIO OF POSSIBILITY . . . . . . . 42

REFERENCES . . . . . . . . . . . . . . . . 46

APPENDICES

A COgnitive ASSESSMENT . . . . . . . . . . 50

B SOCIAL ASSESSMENT ........... . 64

C SHARING ASSESSMENT WITH FAMILIES . . . . . 70 


\section{INTRODUCTION: SCENARIO OF REALITY}

The scene is familiar: report card time is drawing near. Because of that dreary fact, the Play-Doh gathers dust on the shelf, the paints are thickening and congealing in their paint-pots, and the children are slowly transforming from active, curious, explorers to confused, lethargic "students." But don't worry, as dismal as it sounds, it won't last long. In a couple of weeks the teacher will have all of her report cards filled out, and the class can go back to being a whirlwind of discovery and learning--that is, until next report card time rolls around. Then once again we'll see busy-ness abandoned in favor of business: filling out those checklists, marking boxes, scoring screening devices. The children will fade for a while, but the report cards will get filled out and sent home. That's worth it, isn't it? Is it?

\section{BEHIND THE SCENARIO}

As an early childhood educator as well as an inservice provider for early childhood educators, I am well aware that the thorny issue of assessment is one that we get stuck on time after time. It is unfortunate, but all too common, to see early childhood educators using assessment tools which 
have been mandated (or which they perceive to have been mandated) by administrators or legislators lacking early childhood experience or background. Additionally, teachers often enter the classroom without an understanding of assessment issues. It is rare for an undergraduate teacher education program to include course work concerning assessment. Therefore, teachers begin their careers without background or experience that would help them unravel the assessment mystery.

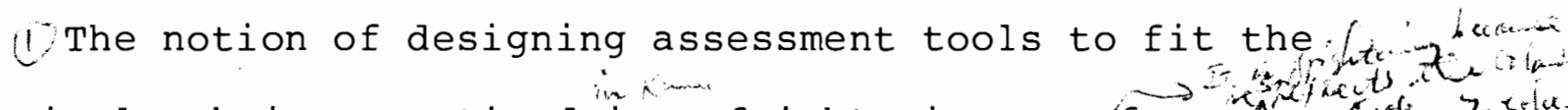
curriculum being practiced, is a frightening one ffor many syste 7 erixteachers, and one which leads them to throw up their hands ${ }_{12} \mathrm{mil}^{\text {tif }}$ and say, "Where do I begin?" The report cards which have been in place and used by teachers who were "here before me" are accepted as status quo because using what is established and accepted may feel safer than breaking new ground with innovative materials of one's own creation. "Therefore, the tools are inappropriate, reflecting neither the curriculum being used in the classroom nor the development of the children being assessed.

As in the scenario described above, when it is time to fill out report cards, early childhood classrooms may, the towe sadzy, abandon exciting rich curriculum order to "assess" children, so teachers can accurately fill out report cards. "itskills which, have not been a part of the ${ }_{\mu} \mathrm{child}$ 's daily routine suddenly become a criterion for reporting to 
parents the set aside in order to collect data on narrowly focused, inappropriate skills.

( 5 In addition, when, teckeport these skills to kingents, wew further an inaccurate perception of what developmental learning jooks like in the early childhood years. A public which may already have concerns about the value of play, experimentation, and child-initiated learning is given a mixed message that we as teachers support an academicsdriven curriculum. When we develop and implement assessment tools which reflect developmentally appropriate practices, we use those tools as another way to educate families, and the public. Our assessment tools and strategies can help inform others about what quality early childhood education is all about.

\section{POTENTIAL FOR ALTERNATIVES}

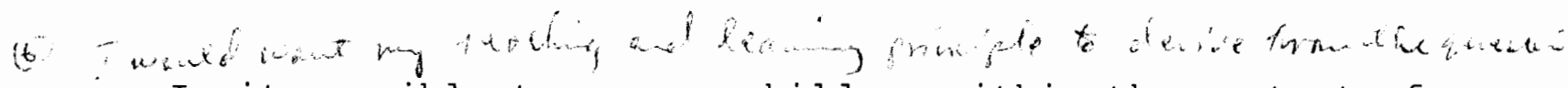
nIs it possible to assess children within the context of the ongoing curriculum? Surely, it should be so: If a curriculum is carefully chosen to foster children's disposition to learn, it could serve as a window for teachers into the child's learning. "The, National Association of state Boards of Education publication Right from the start (1988) offers this inspiration thysig the

We believe that assessment practices for young children should reflect the developmental principles of the curriculum. The Task Force agrees 
with NAEYC (The National Association for the Education of Young Children) that the most important consideration in evaluating and using standardized tests is the "utility criterion"--that is, the purpose of testing must be to improve services for children and ensure that children benefit from their educational experiences.

We recommend that young children be assessed through observation and recording of their developmental progress. Periodic samples of writing and drawings, oral tapes of reading, and video tapes or observations of social interactions and problem-solving become examples in a portfolio for each child. This information should then be used to adapt the curriculum, plan activities to meet the needs of the children, and provide feedback to parents. This type of assessment should take place informally on a daily basis for program planning rather than for placement purposes. (pp. 22-23)

In a similar vein, the National Association for the

Education of Young Children, in Developmentally Appropriate

Practices for Programs Serving Birth Through Age Eight

(Bredekemp, 1987), recommends the following:

Decisions that have a major impact on children (such as enrollment, retention, assignment to remedial classes) are based primarily on information obtained from observations by parents and teachers, not on the basis of a single test score. Developmental assessment of children's progress and achievement is used to plan curriculum, identify children with special needs, communicate with parents, and evaluate program effectiveness. (p. 13 )

And the High/Scope Educational Research Foundation states:

Assessment of children's development, learning, and interests should be an integral part of all early childhood programs. But inappropriate assessment can be a burden on teachers and caregivers--stressful, time-consuming, and unrelated to the day-to-day experiences of the children. (Schweinhart \& McNair, 1991, p. 5) 
(9) These

These powerful and articulate quotes serve to support the need for assessment techniques to accurately reflect the rich, perpetual unfolding of curiosity and discovery that takes place in an early childhood classroom Rather than halt that exciting and natural learning (as in the case of the "Scenario of Reality"), how much more meaningful our assessment will be if it emerges from that learning.

As teachers rely on the ongoing curriculum as the basis for their assessment, they find themselves with a collection of writing, drawing, photographs, tapes and observational notes concerning each of the children in their classes. This wealth of material is much more accurate, in assessing children's development, than a standardized test score or a checklist of skills. What emerges is a profile of children's work often referred to as a "portfolio." 


\section{PORTFOLIOS AS AN EFFECTIVE}

\section{ASSESSMENT VEHICLE}

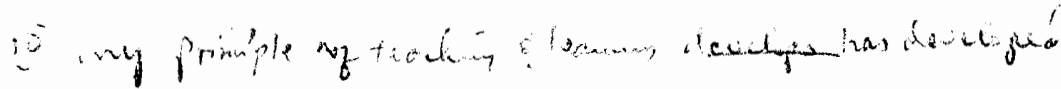

In researching developmentally appropriate assessment techniques "two terms are often seen: "authentic testing" and "portfolio assessment." These terms emerge as important concepts due to teachers' continued dissatisfaction with inappropriate assessment techniques which interrupt, and do not reflect, the active learning in an early childhood classroom. The term "authentic testing" describes assessment techniques used in realistic context, appropriate to ongoing classroom work, reflecting skills or processes beneficial to learners. Used in this way, "portfolio assessment" could be used interchangeably with "authentic testing." The methods described as "authentic" could be used to generate products which would become a student's portfolio.

What exactly is a portfolio? Commonly used by artists, photographers, or writers to showcase their work, portfolios are being used more and more by early childhood teachers to provide a cumulative record of a child's growth and development in the school setting. Portfolio-based assessment has been identified as one of three top curriculum trends by the Association for Supervision and Curriculum Development 
(Vavrus, 1990). At different age levels, portfolios might involve different amounts of student involvement in determining the contents and using them to monitor growth and progress. It is important to note, however, that even a pre-schooler is capable of determining "my best work," "something I really want to save" or "a job I worked hard on."

For the purpose of this thesis, the portfolio is a collection of student work, teacher observation, and parent communication. Within this context, these portfolio items reflect the participation of 4-and 5-year olds in a problem-solving curriculum (Portland Public Schools' Piaget Curriculum, to be described in the next section). The intended audience for this portfolio would include the teacher, assistant, administrator, child and family. "Portfolios are authentic forms of assessment because they reflect real learning activities going on in the classroom" (Vavrus, 1990, p. 52).

Traditionally, and as illustrated in the "Scenario of Reality" which opened this thesis, the major interest of assessment has been outcomes. Admittedly, parents, teachers, administrators and even children themselves have a right to expect certain outcomes as a result of the educational process. But something suffers and is lost when we accept narrow, skills-targeted outcomes as the only piece of the assessment puzzle. In attempting to assess the whole 
curriculum, a portfolio is used to maintain a balance between outcomes and ongoing work (Paulson \& Paulson, 1991). Going one step beyond portfolios as a showcase for children's best work, this thesis presents the notion that a portfolio could successfully showcase the whole curriculum. As later sections in my thesis will explain, the whole curriculum includes cognitive and affective learning, as well as family education. Used in this way, a portfolio will become a lively collection of teacher's goals, reports, student's work, and parent communications.

What is necessary, first of all, in reaching this goal is developmentally appropriate assessment strategies to replace standardized tests, checklists, and outdated report cards. 


\section{DEVELOPMENT OF DEVELOPMENTALLY}

\section{APPROPRIATE ASSESSMENT}

\section{if whentio}

iDevelopmentally appropriate assessment? It almost

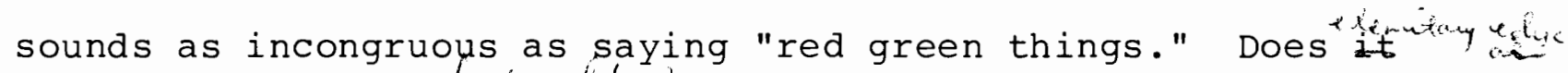

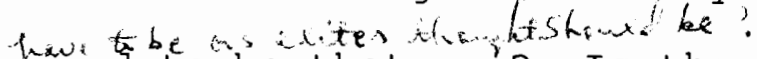

need to be that way? Is there a way to put these two terms together in something that resembles harmony? What needs to be kept uppermost in the educator's mind is the purpose for establishing developmentally appropriate assessment: What is it that we are trying to do, and what information do we hope to gain? This section of my thesis will address these questions, the development and elaboration of my own assessment project, and review of literature which supports this project.

\section{OBSERVATION: A WORTHWHILE TECHNIQUE}

Worthwhile, effective assessment techniques can inform teachers about the development of the children in their classrooms. Observation gives teachers valuable information about children's understanding, interests, and needs. If sime whot wion st the cationst conventional, standardized testing is ineffectual in providing this information for early childhood settings, what can serve as an alternative? Systematic, informed observation of children's activities as they occur in natural settings 
is a principal alternative. While this approach requires time and effort on the part of the teacher/observer, it shaild presents a minimal intrusion into children's day-to-day experiences and therefore has high ecological validity (Goodwin \& Driscoll, 1980) The time that an early childhood teacher spends observing children as an assessment technique is time that delves into, rather than interrupts, the natural flow of developmentally appropriate practices (Schweinhart \& McNair, 1991).

(3) The open, active, informal format of the early childhood classroom allows for integration of innovative assessment techniques into the ongoing curriculum (Wexler-Sherman, Gardner, \& Feldman, 1988). Project spectrum is a research project which seeks to incorporate ecologically valia, alternative assessment techniques and materials into preschool settings. The "Project Spectrum assessment materials" are introduced as choices within the ongoing curriculum. Using this method, children participate in the Project Spectrum activities (and thus are "assessed") voluntarily when they are interested. Tape recorders or written observations serve to document children's competence. Through the implementation of their project, participants are discovering that the process of assessment involves more than merely the construction and administration of tests. Observation of children as they interact with carefully selected materials becomes an effective technique for 
assessing development. Through their project, assessment becomes a natural part of the school day, an interwoven component of the activities occurring in the classroom. This phenomenon attests to the fact that a fusion of assessment and curriculum is possible (Wexler-Sherman et al., $1988)$

In achieving this fusion between assessment and curriculum, teachers will rely heavily on their own observation of children as they interact with materials and their environment. Some observations will be carefully planned and carried out, while some are the result of joyous "accidental" learning that is often found in early childhood

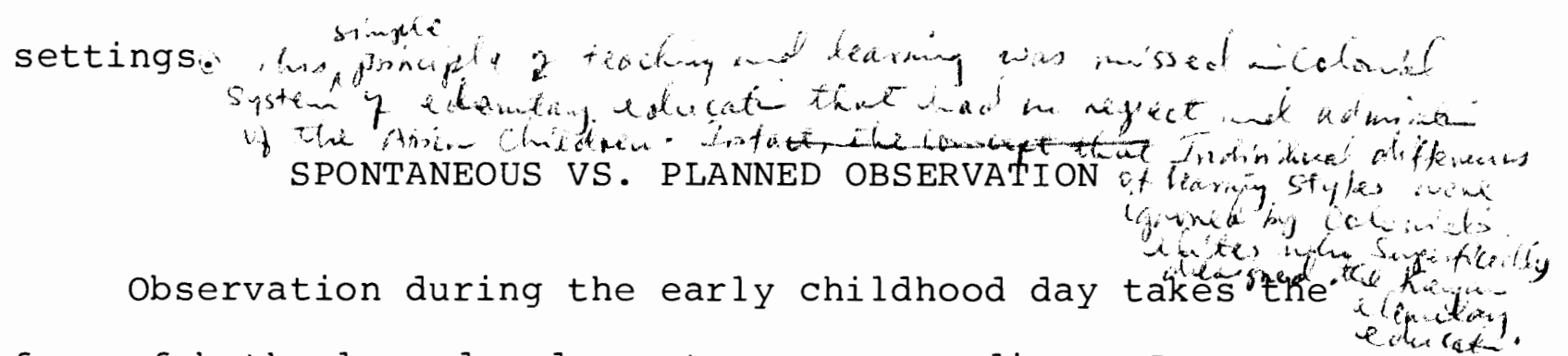
form of both planned and spontaneous recording. Some events sci.s are just too good to pass up, and a teacher will grab pencil and paper in order to record an unexpected observation concerning a child. At other times, a teacher will have a specific focus for what she hopes to annotate concerning a child: Is she using the art area? Is she collaborating with other children on problem solving? Does she take the role of leader, or follower, in group activities?

Both forms of observation are valuable, and neither form is adequate by itself. Much of what is observed can 
provide awareness and insight into each child's interactions with materials and people (Leavitt \& Eheart, 1991). Collected and reviewed over a period of time, these annotated incidents in a child's life begin to emerge as profiles of learning and development. How can the enormous potential of observation as an assessment strategy be harnessed and focused for our benefit and the benefit of children and families we serve?

As early childhood educators examine the need for, and lack of, developmentally appropriate assessment strategies for their programs, an important idea begins to emerge. That is the idea that within every early childhood setting, there are actually two curriculums unfolding simultaneously. The first is the cognitive curriculum, the "planned" or "visible" curriculum. The second is the affective, or "hidden," curriculum. In addition to these two curriculums, sharing the resulting knowledge about children with their families is a major responsibility of teachers. It is these three topics--assessment within the visible curriculum, assessment within the hidden curriculum, and sharing assessment with families--that this thesis will address next. 
THE VISIBLE CURRICULUM

A mandatory partner for developmentally appropriate assessment is, of course, a developmentally appropriate curriculum. For the past several years, I have field-tested and revised Portland Public Schools' Piaget Curriculum. This is a curriculum which was written 7 years ago and has been in constant use since then. The Piaget Curriculum is $*$ one which challenges children on many different levels, while providing rich concept-based experiences. Units of study extend over long periods of time, allowing children to form relationships, theories and concepts as they are surrounded with materials, literature, and thought-provoking problems which invite speculation and experimentation. If what we are hoping to accomplish with our assessment practices is assessment of children's development, learning, interests, problem-solving skills and social interactions, what better place to start than with a curriculum which encourages and supports children as they develop these skills?

The four units which comprise the Piaget Curriculum for 4- and 5-year olds are: Water, Holes, Rocks, and Toys. The central focus of the curriculum relies on presenting children with open-ended problems which invite a variety of 
interpretation. The problems are not ones to sit and ponder, but rather are engaging questions that nudge children out of chairs, off rugs, and into the sand, water, or rocks which fill the classroom. The role of the teacher becomes one which supports collaboration, theory-building, hypothesizing and testing those ideas. No longer the dispenser of knowledge, the teacher becomes free to establish a rich environment, pose meaningful questions, and then observe as children construct their own knowledge. That's a difficult role to master--and one that does not come easily to many teachers. It requires stepping off center stage!

Another noteworthy component of the Piaget Curriculum is that most materials in the classroom are related in some way. Therefore, children are encouraged to experience attributes of those materials in many ways and form theories and ideas about relationships. Using these materials, and each other, children frequently become inventors of new problems, ideas, or theories.

A very powerful component of the Piaget Curriculum is * that of helping children develop, experience, and understand concepts. Rather than experiencing a sequence of activities which are tied together by a common theme, children are introduced to materials, ideas and problems which help them to focus on concepts. For many teachers, parents, and children, this is a new way of learning. For everyone involved, it is tremendously exciting. Hearing children 
make such sophisticated discoveries as "When rocks get broken into smaller and smaller pieces, pretty soon they turn into sand!" or "A sleeve needs a hole at the top and at the bottom, but a pocket better only have a hole at the top!" become common occurrences. Sensitively and accurately recorded, these discoveries become benchmarks for a child's learning. The key to taking advantage of these exciting examples of children's learning is an appropriate means of assessing within the context of the unfolding curriculum.

In any classroom, the curriculum which is most easily discerned is that which fosters cognitive learning. The teacher's carefully orchestrated "lesson plans" reflect this area of the curriculum.

Developmentally appropriate assessment of the cognitive curriculum involved taking a careful look at what it is that I wanted to find out about children. The unique feature of the Piaget Curriculum is its problem-solving base. No other curriculum I have used or reviewed presents children with the wide range of possibilities to construct their own knowledge. Observing and recording this phenomenon, then, became my focus for this portion of the project.

In attempting to design a tool which would assist me in recording children's problem-solving strategies, I needed to take a careful look at what was needed. Certain "record keeping" items are helpful, but not numerous: child's name, which unit is currently underway, which concept is being 
introduced, and which probe words to listen for. "Probe words" is a term borrowed from George Forman and Fleet Hill (1980) in their book Constructive Play: Applying Piaget in the Preschool. They describe this technique in the following way:

Use probe words. By talking with parents, and staff, determine if the child has ever used or been exposed to the word (such as opposite). Begin to use the word in the classroom, in context. Make written observations as children begin to use probe words on their own. We had no fear in speaking words that were very complex in their meaning. Nor should you. What we should all avoid, however, is any attempt to directly teach the child what these words mean. We might stage the environment so that the child does something cooperative, so that we can say "cooperate" in a sentence. That's it. The child makes of the word what she will. We were not trying to direct the child by using these probe words. We were only trying to give ourselves a means to understand the child's view of the physical world. (pp. 90-9l)

The majority of the observation form is kept blank to permit the teacher to take notes in whatever manner works best for her and to record as lengthy a passage as the observation warrants.

Five specific problem-solving approaches are suggested to help focus the observation:

1. Innovation--when a child makes a discovery or develops strategy independently.

2. Cooperation--when two or more children approach a problem collaboratively.

3. Help requested--when a child articulates a desire for assistance. 
4. Leadership offered--when a child offers to help another.

5. "Other" (that all-important category)--because no matter what we come up with, children can always come up with something else!

When put together as a cumulative document, representing each of the concepts covered in the Piaget Curriculum, this sequence of pages represents what would become observational records for a child enrolled in the Piaget program. They would cover the full year (September-June) of the curriculum. Also included are samples of children's individual record-keeping sheets. These represent what might be included in a child's assessment portfolio, but are by no means the only possibilities. They are meant to show that a variety of approaches are used in the curriculum, introduced to children in meaningful context. As childinitiated means of recording discoveries, they become an integral part of the assessment portfolio. (See Appendix A for these items.)

Taken as a whole, they serve to offer valid, lively insight into a child's interaction with the cognitive, or "visible" early childhood curriculum.

These pages alone would certainly provide teachers and families with more information than could be gleaned from a checklist. However, as they deal with the visible curriculum, the picture presented is not complete. What more would 
we know if we were able to tap the rich resources of the affective, or "hidden," curriculum? 
THE HIDDEN CURRICULUM: SOCIAL

LIFE IN THE CLASSROOM

As any early childhood teacher knows, there is much more going on within any group of young children than just cognitive development! Friendships are made, and broken, truces and bargains struck, social skills practiced and enhanced on a minute-to-minute basis. Is there a way for a teacher to observe and record this information as a part of a child's assessment profile?

often, the activity that seems most engaging and exciting in the early childhood classroom is not the activity that the teacher had planned for the day. Looking into the teacher's plan book, an observer ought to be able to guess what will be going on. However, the informal, openended nature of the early childhood setting allows for child-initiated activity as well as that which the teacher has planned. And children bring into the classroom with them such great ideas, and unstoppable energy! It is not at all unlikely for a teacher to be standing in the middle of what she perceives to be "her" classroom, while children carry out their "great ideas," and to be politely told: "Excuse me, Teacher, you're in the way." The message is clear--the child feels confident, empowered, and is acting 
completely independent of the teacher. The hidden curriculum, that of affective rather than cognitive development, often makes itself quite apparent.

\section{WHAT CAN BE LEARNED WHEN THE TEACHER STEPS BACK?}

What if the teacher is willing to accept that comment-"Excuse me, Teacher, you're in the way"--from a confident child? When she steps back from center stage in order to observe what rich social development is happening in her active classroom, what implications do we see for assessment potential?

In facilitating children's social development, the fords ifal teacher must be sure to keep three important assumptions in mind: l) certain over-riding values (justice, liberty, and the avoidance of harm) exist in our classrooms as well as in society; 2) diverse cultural traditions can co-exist with these values; and 3 ) the long task of becoming moral, successful, social beings belongs ultimately to the children (Edwards, 1986).

(18) Another important consideration for the early childhood teacher to keep in mind is that children develop certain social competencies at different ages. During the preschool and kindergarten years, the hallmark for children is the development of peer interaction skills (Waters \& Sroufe, 1983). For a teacher willing to observe these skills as 
they develop, the "hidden curriculum" becomes fascinating-one to embrace rather than shy away fromek...

WHAT IS THERE TO BE LEARNED?

When achievement tests, administered in kindergarten, were used as a predictor of first grade success, test scores explained only $36 \%$ of the variance in children's first grade achievement scores. Therefore, $64 \%$ of first grade achievement is due to factors other than those measured by the Metropolitan Readiness Test (an achievement test). When we included observed behavior, peer nominations, and teacher rating scales, however, we predicted $75 \%$ of first grade achievement. (Pellegrini \& Glickman, 1990, p. 119 )

This quote provides a testimony to the power and accuracy of teacher observation of social competency as a predictor of later academic success. How can social relationships exert such power?

Peer relationships, for young children, allow a chance to interact with equals, which is a different situation from interacting with a teacher. When peers interact, they experiment with a variety of roles, both as leaders and followers; contribute ideas; respond positively or negatively to the ideas of others; and hone their skills as negotiators (Kostelnik, Stein, Whiren, \& Soderman, 1988).

As teachers encourage pro-social behavior in their classrooms, they will find themselves providing on-the-spot adult-guided conflict resolution for any number of situations which may arise and which have never been planned. 
While skits, puppet shows or group discussion focusing on certain recurring situations may be beneficial to young children, the most meaningful intervention will be that which occurs at the same time as the conflict and has its intent firmly rooted in the actual occurrence.

With certain children, and certain situations, a teacher may need to analyze the components of complex social interactions in order to figure out what part of the interaction the child is having problems accomplishing. For instance, in order to behave pro-socially, a child must be able to figure out that another's help would be appropriate (Baron, Byrne, \& Griffith, 1974) and also figure out what behavior to carry out in order to gain that help (Moore, 1982). A sensitive teacher could guide a child as he or she navigates the murky waters of social acceptance. This guidance might take the form of helping a child gain access to a desired play situation. Steering the child toward a smaller group, or a more accepting group, may make for success. A teacher's help may be necessary as a child observes an ongoing play situation and figures out the theme and what he or she might have to offer. Entering play with a strategy such as "Knock, knock. Here is your pizza" might be much more successful than grabbing the baby doll and announcing, "I'm the mom!"

Additionally, a teacher can help children gain skill with the important, but sometimes elusive, language of 
cohesive play: "Can you tell Ryan why you don't want to play with him right now?" Or, "Do you think Lindsay heard you?" Sometimes "prepping" classmates may provide ease of entry into a situation. When Robert approaches the block area and Lucy nervously asks the teacher to "Keep him away from my building," the teacher might ask Lucy if she could be the building supervisor and give Robert some jobs to do. Robert has joined the play, and Lucy still feels as if she's in control of a project she started. The teacher stayed out of the way and yet still managed to gently guide the social life in her classroom. Are there ways in which she can record this activity as it unfolds?

\section{HOW CAN DATA BE COLLECTED?}

In early childhood settings, adult staff may vary from one teacher alone with a group of children to a teacher and assistant working together, to a teaching team of several professionals, to a teacher with volunteer support. Each configuration allows for different opportunities to collect data to support, observe, and record social development.

A teacher alone might utilize anecdotal records of social interactions which she observes, interviews with children to gain information about social perceptions, as well as using the children themselves as informants. Using children in this capacity might involve journals with specific focus questions, tape recordings of conversations, 
or tally charts of certain behaviors. (I have observed a teacher who listens while one child "tattles" on another and then requests that the child add a tally mark to a class "score" or tattling incidents.) Above all, a teacher working by herself with young children should not fall victim to the thinking that, because she does not have additional personnel in her classroom, the world of social development is off limits to her.

With the addition of another adult in the room, such as a teaching assistant or parent-volunteer, the teacher becomes more able to spend time observing, recording, and facilitating social development. A teaching assistant or volunteer may also be trained in recording or interviewing-but matters of confidentiality must be considered, especially with parents.

Not to be overlooked as a rich possibility for data collection are those special circumstances such as student teachers, practicum students, or other "visitors" to the classroom for short-term stays. With a clearly defined focus, it may be possible for such an addition to the classroom to provide a wealth of information on what is going on within the hidden curriculum. 
SEEKING THE HIDDEN CURRICULUM

Running Record of Social

Activity

For the purposes of my thesis, I spent 1 day a week for 8 weeks in an all-day kindergarten class in a public elementary school. In making peer interactions and social development the focus of my observations, I chose a variety of methods for data collection. The first was a full-day running record of five girls. The cooperating teacher had identified these five girls as a group who were socializing to the extent that the activities of the school day had little or no impact on them. In observing them, I began with one and noted what she was engaged in, moved on to the next, and when completed with all five began the cycle again. I kept this up from the beginning of the school day through story time in the afternoon. This was not a technique that would have been feasible for the teacher to undertake, as it had occupied me for nearly a full day. However, since the teacher had capitalized on the addition of another adult to her classroom, she was able to amass a wealth of information concerning this problematic social group. In examining the notes, we discovered that one suspected member was not really a part of the group and that another girl, though a thoroughly entrenched "clique" member, was quite capable of choosing and maintaining an independent activity, when that activity was sufficiently 
interesting to her. We also determined from this first collection of notes (Appendix B) that more information could be helpful in understanding this group dynamic.

\section{Classroom Map}

The next method that I tried, which involved the same group of five girls, was a classroom map. Using a map which showed the areas used by children in the classroom and adjoining hallway area, I assigned each girl a different color ink. I then traced each girl's movement from place to place in the classroom. As the classroom teacher and I took a look at the resulting picture at the end of the day, some conclusions could be drawn: The girl who we had suspected, due to the previous week's anecdotal records, was not a bona fide member of this clique was also shown by the map not to be a member. Her only movement during the morning was to move from the cornmeal table to the Play-Doh table--and not in conjunction with any other clique members. The map showed that the painting easels, Play-Doh table, and woodworking bench were used more as social gathering places than as interest centers. The map clearly showed that all four members of the clique showed up at these places, and a quick additional notation indicated that they gathered there to "chat," not to engage in Play-Doh, painting, or woodworking activities. While this method would have been easier for the teacher to accomplish than a running record, it was much 
simpler for me. Having no official classroom responsibilities, I could focus my attention on data collection and later effectively debrief with the classroom teacher. The data served to give her more information on the workings of this group of girls, and the engagement, or non-engagement, at certain centers could be helpful to her in planning future environmental changes.

\section{Interviews}

As we discussed this group of girls and the amount of power that being someone's friend holds in kindergarten, we became curious about other friendship issues. In order to delve into this question, I designed an interview, comprised of nine questions (Appendix B). We agreed that in addition to questions revolving around friendship, we'd like to get a sense of another issue through the eyes of the children: What were the options and obligations of Choosing Time? We also agreed that it would be worthwhile to interview not just the group I had been studying, but the whole kindergarten class. The interview process took several weeks to complete, but gave us insights into children's thinking about friends. I had assumed that by asking children "which two people do you like best in your class?" I would receive an accurate picture of friendship patterns. I discovered, on the contrary, that friendship at this age is a most fleeting thing--being a "friend" means being a "momentary 
physical playmate" (Rubin, 1980, p. 91). Therefore, if someone had recently been mean to you, you could retaliate by listing other people as your "best" friend, even if the child who had been mean to you was your otherwise constant companion and best buddy. The friend who is playing with you right now is your friend; anyone else may truly be "out of sight, out of mind." This perspective is illustrated in an interview with a 4-year old:

Interviewer: Is it hard or easy to make friends? child: Hard, because sometimes if you wave to the other person, they might not see you wave so it's hard to get that friend.

Interviewer: What if they see you?

Child: Then it's easy. (Rubin, 1980, p. 97)

The teacher with whom I was working felt that these interviews gave her insights into the children in her class in a way that she otherwise might not have had; she took them with her as she filled out her report cards. But had the interview process been left up to her alone, she readily admitted that it would have been insurmountable.

\section{Peer Acceptance}

A fourth technique which I field tested in this same kindergarten class was one which I gleaned from work by Kristen Kemple (1991). It involved observing for particular strategies, or their absence, within the social competence of unpopular children. Based on several research studies (Hartup \& Moore, 1990; Howes, 1988; Ladd, 1990) this method 
involved careful, informed observation of the child. The research mentioned suggested particulars to observe for, such as: problem-solving skills, effective social language, and greater success with small or large groups of peers (see Appendix B).

As I observed one child using this form, it was a simple matter for me to make tally marks as certain targeted behaviors occurred. The form was clear and concise enough so that I was able to simultaneously keep anecdotal records on the same child. At the end of this observation, using both the Peer Acceptance form and my anecdotal notes, I had a fairly complete picture of what had gone on during a short span of time for that child. As his teacher and I reviewed these data, the cluster of tally marks on the Peer Acceptance form around certain issues gave us clear information. As our goal was to gain understanding into why he was unpopular and make decisions about how to help him in his quest for social acceptance, the information we gathered offered us a place to start. The questions taken from Kemple's work offered me a more thoughtful way to focus observations around the issue of unpopularity than I have ever seen.

\section{Anecdotal Notes}

During the course of my weekly visits to this classroom, several other situations arose which clearly could 
benefit from careful observation. I found myself, again and again, relying on the tactic of sitting down with a pen and a blank piece of paper to take anecdotal notes of observed interactions. Without preconceived lists, guidelines, topics, or boxes to be filled, this method often provides the most helpful information. While it is difficult for a classroom teacher to accomplish this on her own, I nevertheless recommend it wholeheartedly. Suggestions for actually getting it done might include: asking an administrator or support staff member to take over in your classroom for a short period of time while you observe; observing on the playground when you may not be called upon quite so often to supervise; observing your class in physical education, music, or other special classes where you are not the leader; or trading "prep" time with another teacher and observing in each other's classrooms. Many techniques are possible; the important thing is getting data collected so that the important work of facilitating social development can get underway.

Maybe the hidden curriculum, the unplanned occurrences, the rich social life unfolding all around in the early childhood classroom doesn't need to be feared; perhaps it can be actively sought. perhaps it can even be welcomed for the wealth of information it can provide to teachers about the children with whom they spend a great deal of time. 
THE EXTRA-CURRICULAR CURRICULUM: SHARING

ASSESSMENT WITH FAMILIES

No child enters school alone. Preschoolers or kindergartners do not independently appear in their first classrooms, ready to meet the teacher and begin their school experience as unconnected entities. The first-day-of-school scene articulates this truth: Tearful mothers or fathers leave young children in the care of Teacher. Sometimes it is a proud, or possessive, or gruff, older sibling who has the responsibility of making sure that a younger child makes it safely to their first day. Even if it was not so visibly obvious that the child who appears in school for the first time is a part of a larger family unit, it is a powerful truth. Possibly at no other time will parents be so proud, so concerned, so involved, so curious and interested in what is happening in their child's school life. What wonderful energy to capitalize on!

Every teacher has curriculum goals: plans for engaging children cognitively during the school year. And every classroom has a life of its own: an underlying, unplanned, unstructured curriculum born of Eriendships, cliques, affective development of all kinds. A third type of curriculum 
is that which involves families in their child's early school experience.

Within my own teaching, this component was one of the last to fall into place. The visible, cognitive curriculum --my "goals" and "lesson plans"--was dictated by my supervisors and was in place by my first day of teaching. The hidden curriculum, that emerging from affective development, although not planned by me was also evident from the very beginning of school. Those were the two pieces I felt comfortable and competent with initially. It took longer for me to feel as if I was making effective use of the school-family connection. But once that connection was made, I continue to be surprised and delighted by how powerful it is.

\section{SHARING ASSESSMENT WITH FAMILIES:}

\section{THE COMPONENTS}

The responsibility of sharing the knowledge and understanding about children that a teacher gleans through appropriate assessment techniques is a complex one. It involves establishing a comfortable relationship with the family, allowing the family to assist the teacher in getting to know the child, and educating families about early childhood education and the accompanying assessment strategies. As the following components will illustrate, a wide range of approaches can be used to accomplish these goals. 
Home Visits

Every september, I begin the school year by making a visit to each one of my students' homes. When I am teaching two sessions of pre-kindergarten, this means I make a staggering 40 home visits. It is an exhausting but rewarding week! Long a mainstay of special education and Head Start programs, home visits "provide the opportunity to maximize the principle that effective educational and human service programs begin where the client is" (Powell, 1990, p. 69). For families who may be uncertain or uncomfortable about school experiences, it is a way to say that the teacher is willing to reach out and meet on common ground to discuss expectations for the coming year. The visit is not intended to evaluate, or judge, the family in any way. The purpose is to say, "I'm glad to meet you and look forward to seeing you at school next week." I take a picture of my future student when I visit (with favorite toy, pet, or family member), and when the long-awaited first day of school arrives, "teacher" is not an unknown face, and there's an exciting picture to look for on the bulletin board. "Home visiting provides unique access to families and extensive information about their situation" (zigler, 1990, p. xil).

During the home visit, I am able to gather pertinent information such as allergies, fears, interests, caregivers, and routines. Registration forms can be left with the 
family, lessening the time they will need to spend in the school office (another potential source of anxiety for some families). Asking them about how they would like to be involved in their child's school experience and informing them of the possibilities, is comfortably and informally taken care of at this time. The purposes and procedures for assessment during the school year can also be informally introduced at this time. While I do not expect to delve deeply into assessment policies during this initial visit, I am able to at least begin to explain what I hope to learn about their child through observations, give them an idea of what to expect in terms of written assessment, introduce the term "portfolio" and explain its use as an assessment vehicle. It provides a chance to get the year off to a good start, by letting families know from the outset that they will be included and involved in assessment.

\section{Classroom Volunteers}

Volunteering in the classroom is probably one of the most traditional ways of being involved in school. Poorly planned for, it can be a dissatisfying experience for teacher and parent alike. When handled carefully, it can be rewarding, and worthwhile. Although certainly not the only sign, "abundant parent participation is a sign of a good program" (Peck, McCaig, \& Sapp, 1987, p. 37). During the home visit, the parent's desire and availability for 
volunteering has been established. After that, I always request that the first few weeks of school take place without parent volunteers in the classroom. This gives the children and me a chance to get to know each other, establish routines, and separate comfortably from parents. When those first few weeks are over, I schedule a meeting where interested volunteers can hear from me what their responsibilities may involve. A supportive, understanding practice is to hold this meeting directly at the end of the school day. A teaching assistant supervises children as they play, while the prospective volunteers meet with me. If possible, slides of "A Day in the Life of Your Pre-Schooler" can be shown, illustrating possible volunteer roles. I give the volunteers a schedule, show them coat and purse areas, and explain what their part in the daily routine will be. They have a chance to tell me what they are enthusiastic or apprehensive about ("I love to read out loud to children, but I don't feel comfortable with art projects"). Having this time beforehand for sharing information and asking questions goes a long way toward eliminating problems before they start. "Research is very clear about the benefits of parent participation for their child's education" (Peck, McCaig, \& Sapp, 1987, p. 39).

Family members who spend time volunteering in the classroom will have the benefit of seeing developmentally appropriate assessment in action. Perhaps more powerful 
than any other means of "getting the message across," they will be able to observe the teacher as the teacher observes children. They will also be privileged to see children and teaching staff making suggestions and decisions about items to be included in a child's portfolio. As families see these strategies in action, concepts that might have been confusing begin to gain real meaning through application. It is hopeful that they will be able to see first hand that authentic, ongoing assessment is more accurate and less disruptive than "testing" for report cards. Each time we reinforce that point, we gain potential allies!

\section{Parent-Teacher Conferences}

Once the school year is underway, a major responsibility of teachers is reporting to families. How is my child doing? Is she making friends? Is she making progress? What can I do to help at home? These are questions that concern parents of young children. This information can be shared at parent-teacher conferences, through informal communication, and through reporting tools such as "progress reports."

Conferences are an integral part of the education process and cannot be regarded as impractical or unnecessary (Stone, 1987). Parents may feel anxious about coming to school for what they perceive to be a formal evaluation session, and there is much that a thoughtful teacher can do 
to put parents at ease. A pre-conference questionnaire can be used to gain information about questions and concerns parents may want to discuss. Comfortable, adult-sized chairs, coffee, or tea can help to create a relaxed atmosphere. If the teacher has in mind a structured, but not rigid, approach to the conference, she will feel more at ease herself. Sharing observations that she has made concerning the child's cognitive discoveries, social development, special interests, and friendships are all worthwhile and bound to be of utmost interest to parents. It's important not to neglect to allow time for the parents to share with you what have been their perceptions about their child's school experience. What sort of reactions did they notice, what does the child talk about at home, what events and discoveries have been met with most enthusiastically? "During conferences, teachers learn details of the child's interests and behavior at home and gain insight into parental hopes for the child" (Stone, 1987, p. 27).

The parent-teacher conference is the perfect time to share the contents of a child's portfolio. Families can be informed about how and why certain projects were undertaken --what were your "goals" for their child? Emerging skills and interests can be pointed out; what words does the child undertake to write on her own, what projects were independently instigated? The conference becomes a cooperative venture for getting to know the child better. 
Written Reports

There will be other times during the school year when the luxury of an appointed time to meet with each family, as in the home visit and the conference, is not feasible. At these times, "report cards" may serve to let parents know what the school experience is providing for their child. Traditional report cards consist of a checklist of skills, with the teacher's check marks or other coded notation indicating mastery or further work needed. This type of reporting tool tells families little about their child's active learning, discovery, peer relationships, or interaction with the classroom environment. A common scene after report cards have been handed out is parents quickly tallying check marks and then comparing with other parents. This type of "measuring up" of one child to another can only serve to promote competition, boasting, gloating, disappointment, and an inappropriate view of the environment we try to establish for children. These are not attitudes I wish to foster in my own teaching situation.

Throughout the years, I have paid careful attention to what it is that parents want to know about their child and the school experience, as well as what sort of parent education I can accomplish through my reporting system. Not without much trial and error have I settled upon two successful reporting tools. 
The first is a simple narrative which breaks the early childhood day into its routinely occurring events: group meeting time, work time, small group time, snacks, story and outside time (see Appendix C). Ample space is left after each heading for the teacher to write a narrative comment illustrating favorite times, chosen activities, times which are often less successful, and emerging interests and skills which she may have noticed about each child. Copies of portfolio items could be attached to this narrative in order to help the school experience come to life for families. The personal nature of this "portrait of my child's day" has touched many families in a way that a checklist could not. The second tool which I devised, and which has been successfully field tested in a number of settings, is a classroom map (see Appendix C). The classroom environment is sketched onto a sheet of paper, simply labeled--with most of the space left blank. The procedure for "filling out" this reporting tool is similar to the narrative mentioned above, the focus being use of space rather than use of time. Areas the child frequently, or seldom, chooses to work in can be easily noted as the teacher writes anecdotal notes about the child's use of classroom space: "Bethany can often be found at the Invention center, teaching others how to make some of the creative inventions she comes up with." Or, "Joshua seldom chooses to work at the water Table, although during small group time he successfully siphoned 
water from one level to another." Again, portfolio items, or copies, could be attached to this report, along with a label noting where in the classroom this work was undertaken, in order to strengthen an understanding of the child's use of the environment. Families have the joyous sense of "being there" as their children engage in active learning, a sense which may not be successfully conveyed through traditional report cards.

\section{Parent Education}

The final component of family involvement is that of parent education. Surely this component is included in all areas already discussed: home visits, volunteering, conferences, and reporting. All of these hold possibilities for underlying parent education. Each time we communicate with parents about our goals, our routines, our materials and our observations about children, we share valuable information about appropriate education and assessment. There may be times, however, for a more obvious focus on parent education. "Early childhood educators must assume the responsibility for understanding and articulating developmentally appropriate education to parents" (Bredekemp, 1987, p. 86). Several times during the year I plan Parent Nights, supporting busy families by always arranging child care. Parents are then free to join other parents, and me, in learning together about early childhood education. The format may 
include a slide presentation, video recordings of their children in action, or hands-on discoveries similar to what their children participate in during the school day. As the discoveries unfold, parents are informally and comfortably introduced to what developmentally appropriate education and assessment looks like. A teacher can capitalize on parent involvement by taking anecdotal notes as parents work on classroom activities. When shared, these notes provide a meaningful example of what insight into learning teachers hope to gain by utilizing these assessment strategies. Parents could begin to create their own "portfolio," thereby gaining an understanding of the process involved in choosing items for inclusion in this important collection. Questions can be asked and supportively answered. If further information or explanation is desired, private conferences can be set up.

Parent Nights are another way to say that families are a welcome part of the school experience and that involving them in assessment practices is an important goal.

In conclusion, I restate that no child comes to school alone. Each child who bursts or shuffles into the classroom, or hangs shyly about the doorway, in september is a part of a family. Each door that we open to active family support, involvement, and understanding of appropriate assessment creates benefits for the children we nurture. 


\section{CONCLUSION: SCENARIO OF POSSIBILITY}

It is report card time again. The pre-school teacher does not bat an eyelash, nor does she sway from her normally unfolding, action-packed routine. Instead, she takes a few snapshots of particularly exciting projects and slips them into the appropriate children's portfolios. As she notices that Ashley and Kenya have successfully figured out for the first time who's going to be the mother and who's going to be the babysitter, she pulls out her anecdotal notes and records this developmental landmark. Having discussed social development at her last Parent Night, she knows that Ashley and Kenya's families will be as overjoyed as she is by their accomplishment. Because she shared with families the powerful technique of recording her observations of children's development, she sends a copy of this record home with both girls, as well as including copies in each portfolio. The naturally busy and productive early childhood curriculum is being used to facilitate assessment. It is a very different scene from the one which opened this thesis, in which the active curriculum was set aside in order to fill out report cards. In that case, the early childhood curriculum was being stifled for the sake of inappropriate assessment. 
This thesis work has made several contributions which could be of value to practicing early childhood professionals. First, it has offered reinforcement and support to the notion of using portfolios as an assessment technique. In attempting to use authentic testing, rather than standardized or skills-based testing, as a means to determine student development, portfolios stand out as a vehicle for reflecting children's progress. The collection of student's work, teacher's observations and parent communications provides a more complete picture of the child's learning.

Another contribution has been the focus on problemsolving skills in assessing cognitive development. As early childhood teachers strive to provide children with materials and experiences which will foster life-skills, problem solving becomes a crucial focus. Facts and figures may change overnight, but a child who is capable of looking at a problem from several perspectives and coming up with an innovative solution has a resource which will not become obsolete. The concept-based Piaget Curriculum, and the careful observation by teachers of children's problemsolving skills, offers a unique perspective on children's development.

The collection of methods for accumulating data concerning children's social development provides helpful suggestions for classroom teachers. The variety of approaches and foci address a wide range of issues, from 
"How can I successfully accomplish anecdotal observations when I am the only adult in my classroom?" to "How can I help an unpopular child become more adept at entering others' play?" Since an early childhood classroom functions as a daily laboratory in social skills, these methods and suggestions can be regularly used.

As teachers struggle to provide meaningful connections between children's homes and the school, practices such as home visits and parent education should not be overlooked. A vital link in implementing developmentally appropriate assessment techniques will be convincing families of their worth and importance. One teacher's work to build a strong bridge between families and schools is outlined here.

A most useful follow-up to this thesis would be a careful, systematic field testing of all the components of the whole curriculum. Along with this implementation, review and feedback by participants would provide worthwhile information concerning the successful portions of the assessment profile as well as portions which need changes or restructuring. While certain portions have been used informally, there has to date been no systematic field testing and feedback. Response from teachers, administrators and families would be a valuable addition to this work. The premise with which I began my thesis has been strengthened through research, review, and careful consideration. That premise was two-fold: That assessment is most 
valuable when it arises from naturally occurring learning, and that teachers feel most positive about assessment procedures when they have had some input into the creation of the tool itself. This quote from an early childhood educator is eloquent:

If I could change one thing about teaching, it would be to limit the busywork of evaluating children. I feel like I spend the whole first month out in the hall testing one child at a time, when I should be in the classroom with all of the children. To top it off, when I've finished the testing, the information that I am left with is not useful in my teaching. What I need is something meaningful. (Schweinhart \& McNair, 1991, p. 4)

Those words ring true for many of us; perhaps assessing the whole curriculum, and keeping meaningful portfolios which reflect this assessment and are shared with families, is a step toward the "scenario of possibility." 
REFERENCES

Ames, B., \& Ilg, F. L. (1976). Your four year old: Wild and wonderful. New York: Delta.

--- (1979). Your five year old: Sunny and serene. New York: Delta.

Balaban, N. (1987). Learning to say goodbye. New York: New American Library.

Baron, R. A., Byrne, D., \& Griffith, W. (1974). Social psychology. Boston: Allyn \& Bacon.

Best, R. (1983). We've all got scars. Bloomington: University of Indiana Press.

Bredekemp, S. (Ed.). (1987). Developmentally appropriate practice in early childhood programs serving children from birth through age eight. Washington, DC: National Association for the Education of Young Children.

Cauley, K., \& Tyler, B. (1989). The relationship of selfconcept to prosocial behavior in children. Early Childhood Research Quarterly, $\underline{4}(1), 51-60$.

Chaille, C., \& Britain, L. (1991). The young child as scientist: A constructivist approach to early childhood science education. New York: Harpercollins.

Curry, N. E., \& Johnson, C. N. (1990). Beyond self esteem: Developing a genuine sense of human value. Washington, DC: National Association for the Education of Young Children.

Damon, W. (1988). The moral child. New York: The Free Press.

Edwards, C. (1986). Promoting social and moral development in young children: Creative approaches for the classroom. New York: Teachers College Press. 
Fischer, K., Hand, H., Watson, M., Van Pparys, M., \& Tucker, J. (1984). Putting the child into socialization: The development of social categories in preschool children In Lillian Katz (Ed.), Current topics in early childhood education (pp. 103-110). Norwood, NJ : Ablex.

Forman, G., \& Hill, F. (1980). Constructive play: Applying Piaget in the Classroom. New York: Brooks/Cole.

Galinsky, E. (1988). Parents and teacher-caregivers: Sources of tension, sources of support. Young Children, $\underline{44}(3), 4-12$.

Goodwin, W. L., \& Driscoll, L. A. (1980). Handbook for measurement and evaluation in early childhood education. San Francisco: Jossey-Bass.

Hartup, W., \& Moore, S. (1990). Early peer relations: Developmental significance and prognostic implications. Early Childhood Research Quarterly, 5(6), 19-30.

Hohmann, M., \& Weikart, D. (1983). Young children in action. Ypsilanti, MI: High/Scope.

Howes, C. (1988). Peer interaction of young children. Monographs of the Society for Research in Child Development, 217, 17-23.

Kagan, S., \& Rivera, A. (1991). Collaboration in early childhood education: What can and should we expect? Young Children, $47(1), 51-56$.

Kemple, K. (1991). Preschool children's peer acceptance and social interaction. Young Children, $\underline{46}(5), 47-54$.

Kostelnik, M. J., Stein, L. C., Whiren, A. P., \& Soderman, A. L. (1988). Guiding children's social development. Cincinnati: Southwestern.

Kramer, R. (1982). In defense of the family. New York: Basic Books.

Krechevsky, M. (1991). Project Spectrum: An innovative assessment alternative. Educational Leadership, $\underline{48}(5)$, 43-48.

Ladd, G. W. (1990). Having friends, keeping friends, making friends, and being liked by peers in the classroom: Predictors of children's early school adjustment? Child Development, 61(3), 16-22. 
Leavitt, R., \& Eheart, B. (1991). Assessment in early childhood programs. Young Children, $\underline{46}(5), 4-9$.

LeVan, R. (1991). Clinical sampling in the assessment of young children with handicaps: Shopping for skills. Topics in Early Childhood Special Education, 10(3), 6579 .

Maeroff, G. The school-smart parent. New York: Basic Books.

McBride, B. (1989). Interaction, accessibility, and responsibility: A view of father involvement and how to encourage it. Young Children, 44(5), 13-19.

Moore, S. G. (1982). Prosocial behavior in the early years: Parent and peer influences. In B. Spodek (Ed.), Handbook of research in early childhood education (pp. 65-81). New York: Free Press.

National Association of State Boards of Education. (1988). Right from the start. Report of NASBE task force on early childhood education. Alexandria, VA: Author.

Paulson, F., \& Paulson, P. (1991). The making of a portfolio. Pre-publication draft.

Peck, J., McCaig, G., \& Sapp, M. (1987). Kindergarten policies: What is best for children. Washington, DC: National Association for the Education of Young Children.

Pellegrini, A., \& Glickman, C. (1990). Measuring kindergartner's social competence. Young Children, $45(4)$, 40-44.

Powell, D. (1990). Homevisiting in the early years: Policy and program design decisions. Young Children, $\underline{45}(6), 65-73$.

Rubin, Z. (1980). Children's friendships. Cambridge: Harvard University Press.

Schweinhart, L., \& McNair, S. (1991). The new child observation record. High/Scope Resource, $\underline{10}(3), 4-7$.

Sobol, T., \& Sobol, H. (1988). Your child in school. New York: Arbor House. 
Stone, J. (1987). Teacher-parent relationships. Washington, DC: National Association for the Education of Young Children.

Vavrus, L. (1990, August). Put portfolios to the test. Instructor, pp. 48-53.

Waters, E., \& Sroufe, L. (1983). Social competence as a developmental construct. Developmental Review, 100(1), 48-53.

Wexler-Sherman, C., Gardner, H., \& Feldman, D. (1988). A pluralistic view of early assessment: The Project spectrum approach. Theory into Practice, 27(1), 77-83.

Wolff, S. (1989). Childhood and human nature. New York: Routledge.

Zigler, E. (1990). Foreword. In S. J. Meisels \& J. P. Shonkoff (Eds.), Handbook of early childhood intervention (pp. ix-xiv). New York: Cambridge University Press. 
APPENDIX A

COGNITIVE ASSESSMENT 
Child's name:

Unit: Water Holes Rocks Toys

Concept :

Problem-solving strategies to observe for:

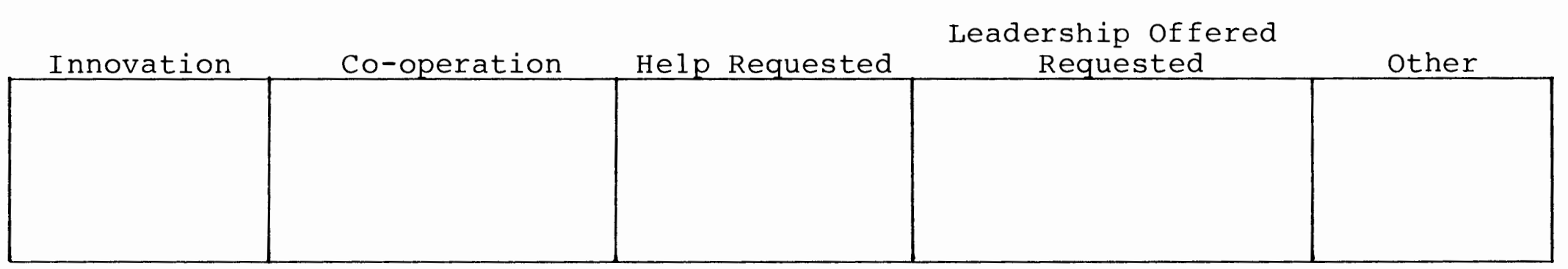

Child's name:

Unit: Water Holes Rocks Toys

Concept:

Problem-solving strategies to observe for:

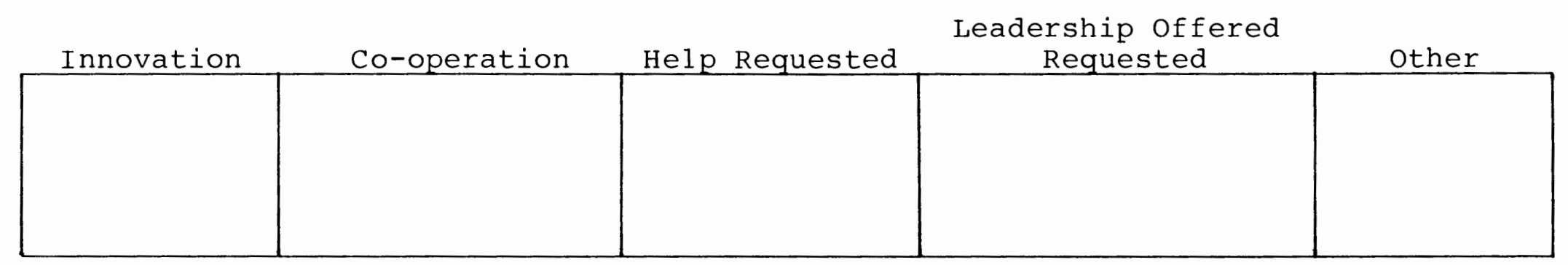


PIAGET CURRICULUM: CONCEPTS AND PROBE WORDS

\section{WATER UNIT}

\begin{tabular}{ll} 
Concepts & \multicolumn{1}{c}{ Probe words } \\
Water has no shape of its own & $\begin{array}{l}\text { shape, container, } \\
\text { prediction }\end{array}$ \\
$\begin{array}{l}\text { Some things sink in water, and } \\
\text { some things float }\end{array}$ & $\begin{array}{l}\text { sink, float, graph, } \\
\text { invention }\end{array}$ \\
Some things disappear in water, & $\begin{array}{l}\text { disappear, dissolve, } \\
\text { record }\end{array}$ \\
Water can change forms & $\begin{array}{l}\text { steam, solid, freeze, } \\
\text { frozen, liquid }\end{array}$ \\
Water can change other things & evaporate
\end{tabular}

HOLES UNIT

Concepts

Holes are found in many places

We use holes for many things
Probe Words

hole, inspector, collection

entrance, exit, container

ROCKS UNIT

Concepts

There are many kinds of rocks

Rocks can be changed

Some rocks are used in special ways
Probe Words

round, flat, smooth, rough

goggles, safety, shards, grains

cement, magnetite, crystal, gems 
TOYS UNIT

Concepts

Toys are different from tools

Toys come from toy stores, or departments

Toys have attributes that describe their use

Everyone uses toys

Toys come from all over the world
Probe Words

classify, group, tools

department, factory

describe, roll, bounce, target

interview, survey, information, record, hobby

celebrate, similar, different, import, export 
54

WATER UNIT

Children use zip-lock baggies and rubber bands and are asked the question: "Can you make water into a different shape?" They trace their bag as a recording of their experiment. Different colored crayons (water-proof!) for tracing can clearly show changes in shape, due to numerous experiments.

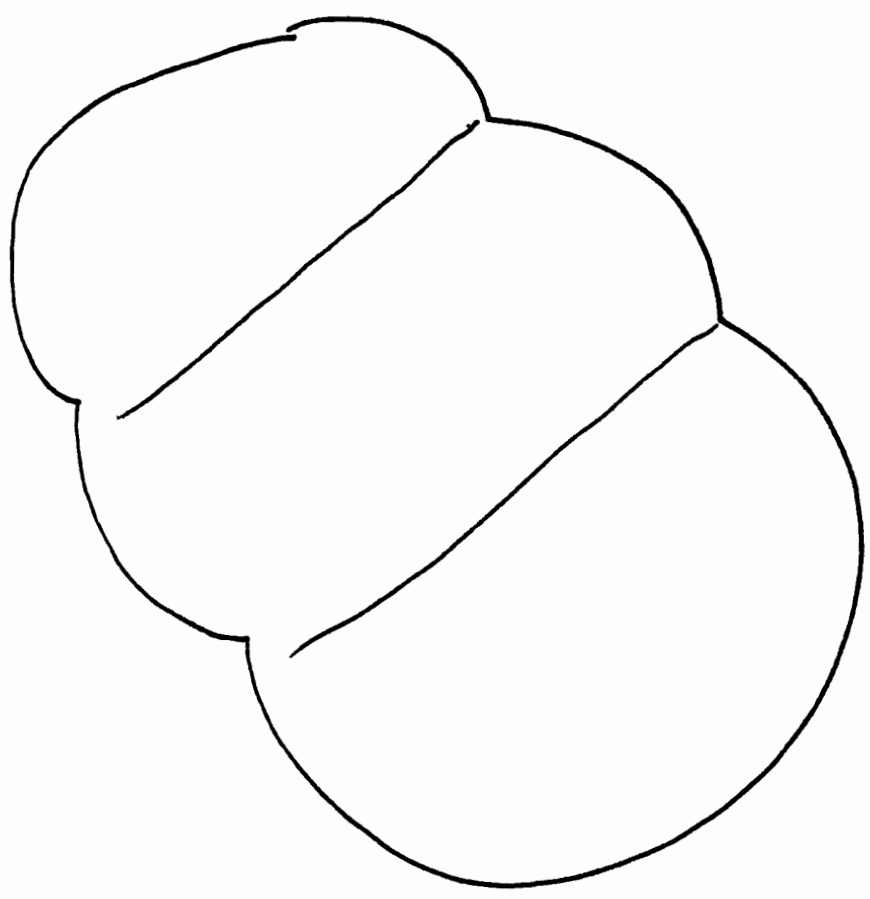

I made water into a snowman shape. 
WATER UNIT

An introduction to graphing. Actual graph would be large, with room for children to place objects on graph after experimenting.

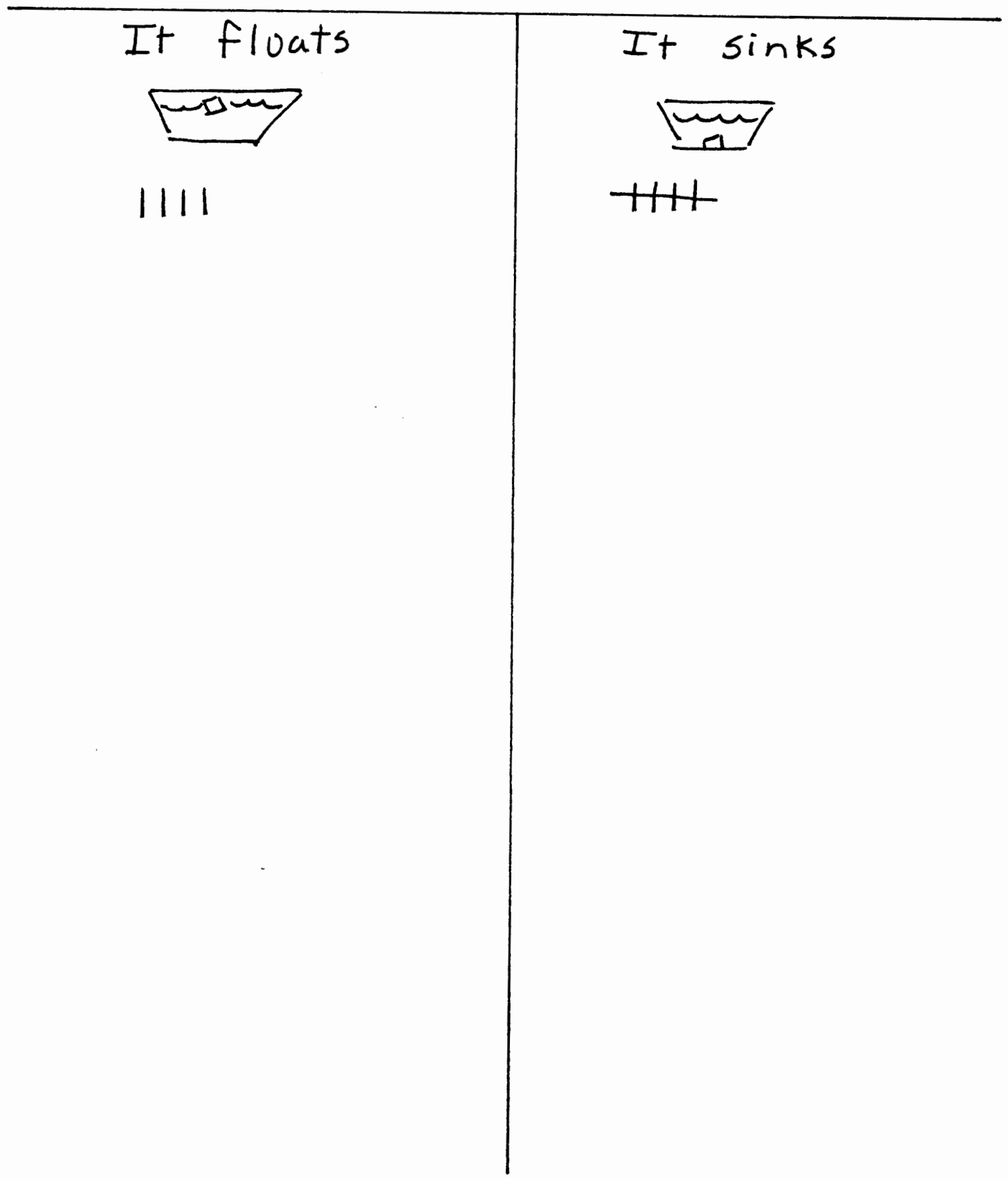


WATER UNIT
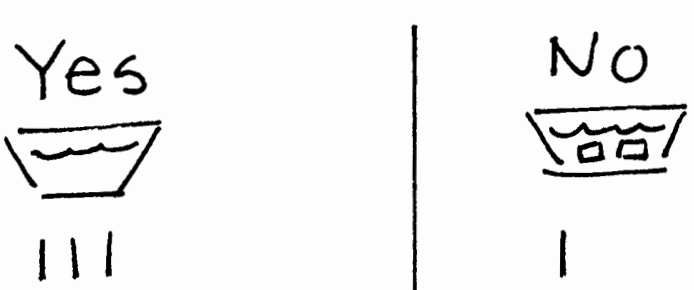

A liftle

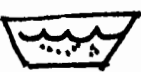

1

This records children's responses to th\& question: "Do these things dissolve in water?" Depending on experience with graphing, either objects or tally marks can be used as recording method. 
HOLES UNIT

Crayon rubbings: A method for recording observations.
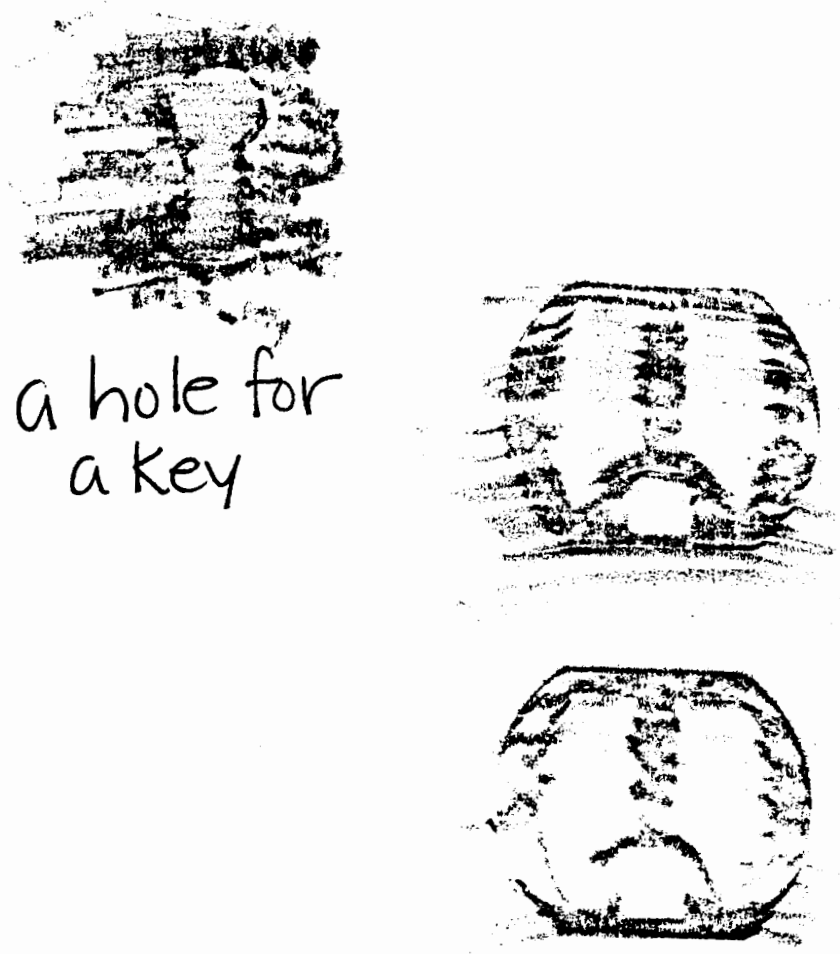

a hole for a plug 
58

HOLES UNIT

Recording via drawing/representation and dictation. "Who I ives at your house?"

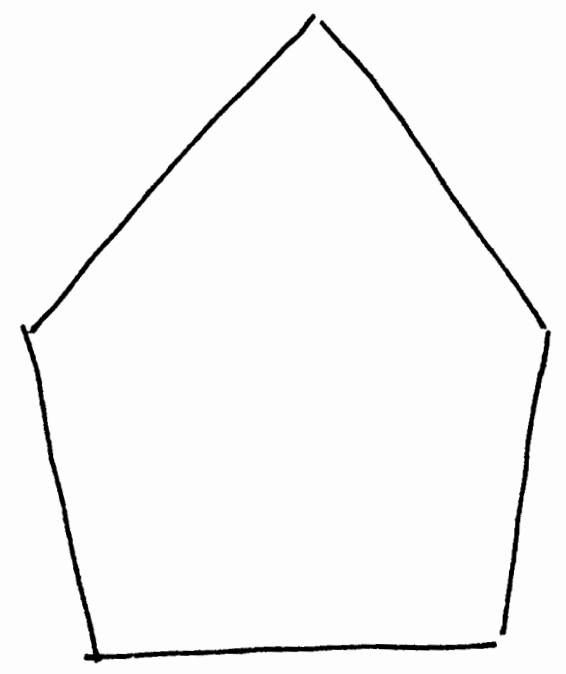

My house is a hole for and me. 


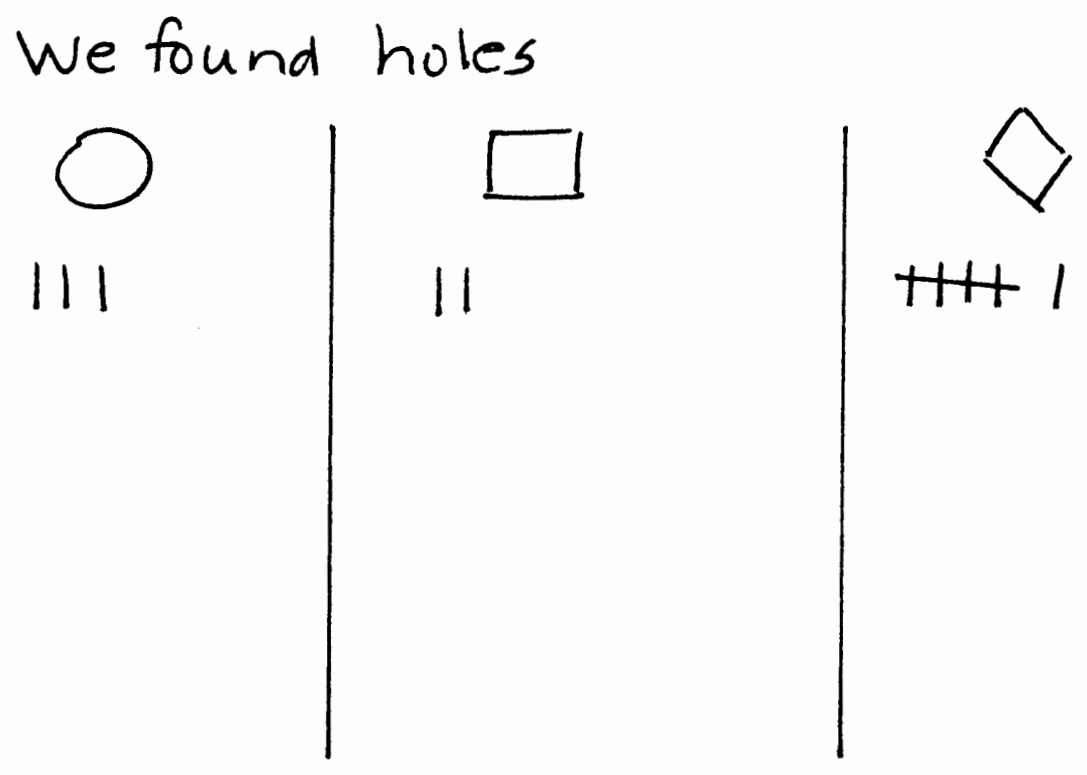

This would occur in January, when children are "experts" at recording. This page would be used individually, with a clipboard and self-made "Hole Inspector" hat. A search of the classroom and school turns up differently shaped holes, which are tallied. 
ROCKS UNIT

\begin{abstract}
MY ROCKS
Here in this box, I keep my rocks

They come from underground.

Some are round, some are plain,

Some are tiny as a grain--
\end{abstract}

My favorite one is

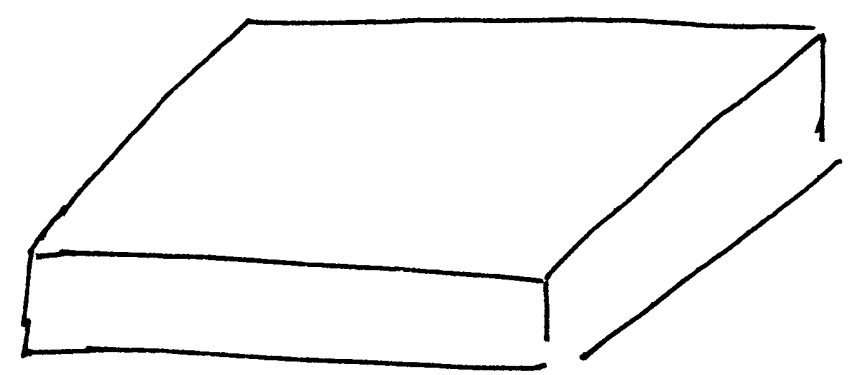

This poem is learned early in the Rocks Unit and is part of a game. This sheet does not involve "reading"--just a chance to add descriptive words, representation, and share with family. 
ROCKS UNIT

I FOUND A ROCK THAT WRITES

Recording through experimentation: black and white paper are provided for maximum "testing" of samples. 
TOYS UNIT

THE RULES FOR ROCK KNOCK-DOWN

Choose a pointy stand-up block. stand back by the book shelf. Roll a round rock at the bluck. Give someone else a turn.

A group recording endeavor--small groups invent a game and then dictate the rules so that others can learn it. 
TOYS UNIT

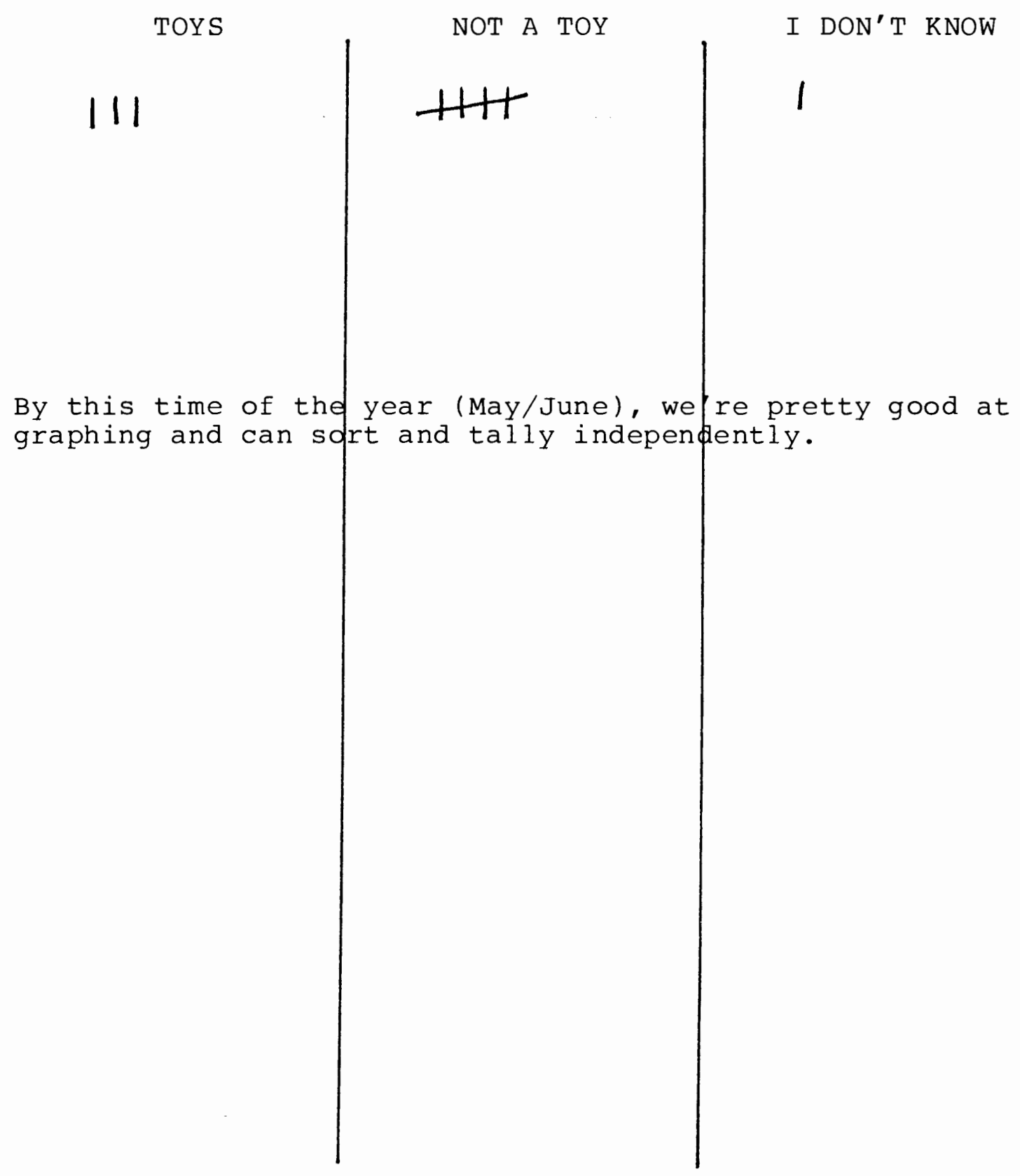


APPENDIX B

SOCIAL ASSESSMENT 


\section{LAKESHIA}

Coloring with Erica and Yorda, making a book for Nedra (the music teacher)

10 minutes later, still working on book

15 minutes later, still working

With Ebonee and LaToya moving around at clean-up time (not cleaning up)

Sucking thumb, curled up next to Ray-Ray at rest time

Resting next to Ray-Ray, back turned, sucking thumb

Interacting with Ray-Ray--JoAnn moves her

JoAnn distracted; Lakeshia moves back next to Ray-Ray and is removed

End of rest time "Ray-Ray, will you wait for me?"

Out in hall after rest time, returned by Ms. Casson-Taylor (counselor)

Sitting beside Ray-Ray at story time

CHIQUITA

Chose to work with ramps, but panics and checks where others are before beginning. Rolls foil ball back and forth while watching the rest of the "clique" at McDonald's (dramatic play center). Leaves ramps to become customer.

Painting. 'Says to me: "You're still here? I know you; you're the one who gave me my shot." (Has misidentified me as nurse, I guess.)

Wiping brush off on cup so that paint drips down outside of cup. Paints for 10 minutes.

Cleaning up in block area

At lunch time, last one eating, last one cleaning table, last one to bathroom, last to lie down to rest (away from others)

Cleaned up (after rest time). Gently waking others

Sat alone by JoAnn at story time 
RAY-RAY

Painting with Allegra. Lots of time spent washing paint drips off shoes. Painted pieces of tape to hang picture.

Taking orders at McDonald's: "You have to pay. I'll get you some money."

When I next look for her, she's nowhere to be found--in the bathroom w/Ebonee. Came out, looked at ramp experiment, "What are you doing?" to workmen, looked at children painting, went to McDonald's.

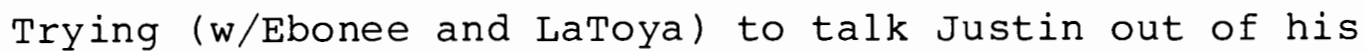
apron: "You have to leave now; we're closed."

Reminder from JoAnn about where she should clean up

Chose rest spot between LaToya and Lakeshia. Tried to refuse to let Catherine rest between Ray-Ray and LaToya. Catherine moved. Came back: "Mind if I sleep here?" RayRay: "You're allowed."

"Resting" with doll, head on hands, chatting with Lakeshia and LaToya.

Holding hands with Ebonee and touching Lakeshia--JoAnn stopped

Out in the hall after rest time, brought back in by Ms. Casson-Taylor (counselor)

sitting by Lakeshia at story time

LATOYA

With Ray-Ray, painted tape to hang up pictures

Working at McDonald's: We open at 8:30. The address is 34 5 th."

To Ray-Ray: "This is our money. It's closed. Turn it to open. And stop acting like a mom. You ain't no mom. You guys gotta' get out; it's closed."

Carrying around name tags for lunch tables (at clean-up time). She's managed to convince Mrs. Brannon (assistant) that she should arrange them. JoAnn returns name tags to Mrs. Brannon.

Walking around before rest time w/pillow and blanket 
Rest near (but w/o body contact) Ebonee and Ray-Ray. Allegra touches her.

out in hall after rest time, returned by Ms. Casson-Taylor Sitting by Ebonee at story time EBONEE

At water table with Garrett. Asks him: "Where's your partner?" Garrett: "You mean my girlfriend? I don't have a girlfriend." Ebonee: "Now you putting words in my mouth. I didn't say girlfriend; I said partner."

Filling bottles, watching sand table action. Offered me "coffee."

Calling to Ray-Ray (nowhere in sight). Went and got her from the easel--Ray-Ray came to look, then went back to painting.

Not to be found--in the bathroom w/Ray-Ray

Followed Ray-Ray to McDonald's, ordered 2 Big Macs and a Coke

JoAnn reminded her to clean up

In and out of room at rest time, calling to Lakeshia

"Resting" w/doll, chatting

Reaching to hold hands w/Ray-Ray

Out in hall after rest time, returned by Ms. Casson-Taylor

Sat by LaToya for story time

Left group time to see what Mrs. Brannon (assistant) was doing in other room

In debriefing and looking over the information that these anecdotal notes give to us, JoAnn and I agreed that another component might be helpful here. The next time I come to her room, I plan to map this same group of girls to see if that picture lends us more insight to what's happening. 


\section{INTERVIEW}

1. Which two kids do you like best in your class?

2. What do you like about ?

3. What do you like about ?

4. What do you like to do at choosing time?

5. What are you supposed to do at choosing time?

6. How can you tell if someone is your friend?

7. Do friends fight? What do they do when they fight?

8. How do friends help each other?

9. Do grownups have friends? How do you know? 
PEER ACCEPTANCE AND SOCIAL INTERACTION

1. Does the child have greater success interacting with: one or two peers? large group?

2. Does the child often seem to misinterpret apparent intentions and emotional cues of other children?

3. Does the child consistently resort to aggression as a means of solving problems?

4. Does the child have more appropriate alternatives to problem-solving at his or her disposal?

5. When rejecting a playmate's suggestion, does the child provide reason or alternative suggestion?

6. Does the child make seemingly irrelevant responses to playmate's communications?

7. Does child ignore questions and comments directed to him or her?

8. Do others consistently rebuff or ignore the child's attempts to engage in play, even when she or he is using strategies that "should" work?

Taken from K. Kemple, Preschool children's peer acceptance and social interaction, Young Children, 46(5) (1991). 
APPENDIX C

SHARING ASSESSMENT WITH FAMILIES 
Dear Families,

Below are observations I have made as your child made her way through a busy school day. I hope they prove useful to you as you share discoveries! Please feel free to contact me with questions or comments.

Very sincerely,

Morning Meeting Time:

Plan-Do-Review:

Outside Time:

Small Group Time: 
June 1991

Dear Families,

One of my very favorite parts of teaching four and five year olds is sitting back and watching as they make discoveries, use language, make friends, and just generally make sense of their world. It's also a very rewarding part of this job--I discover daily how much children are growing and learning all the time!

The attached page is a map of our classroom. The room has been carefully arranged so that it fosters independence, cooperation, and learning. On the classroom map, I have noted some of the things I've observed about your child. My observations may include activities your child is likely to choose again and again, or activities your child rarely chooses. Areas your child prefers to work in alone may be noted, as well as the areas that serve as social gathering places.

I hope that my notes serve to give you an idea of what the Pre-school experience has been like for your child. It's been one that I have very much enjoyed. Thank you for sharing your children with me!

$$
\text { Sincerely, }
$$




\section{CLASSROOM MAP}

\section{Windows}
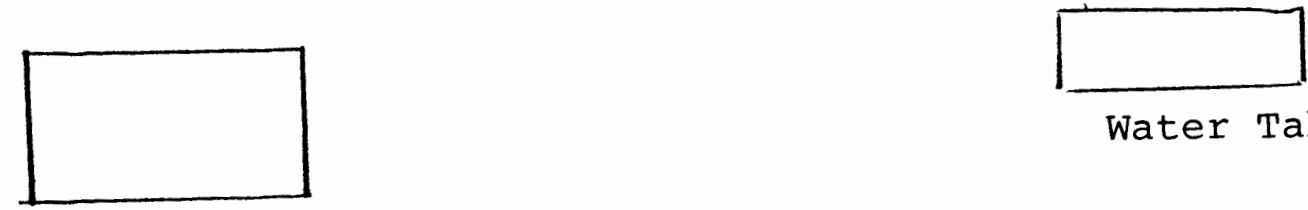

Water Table
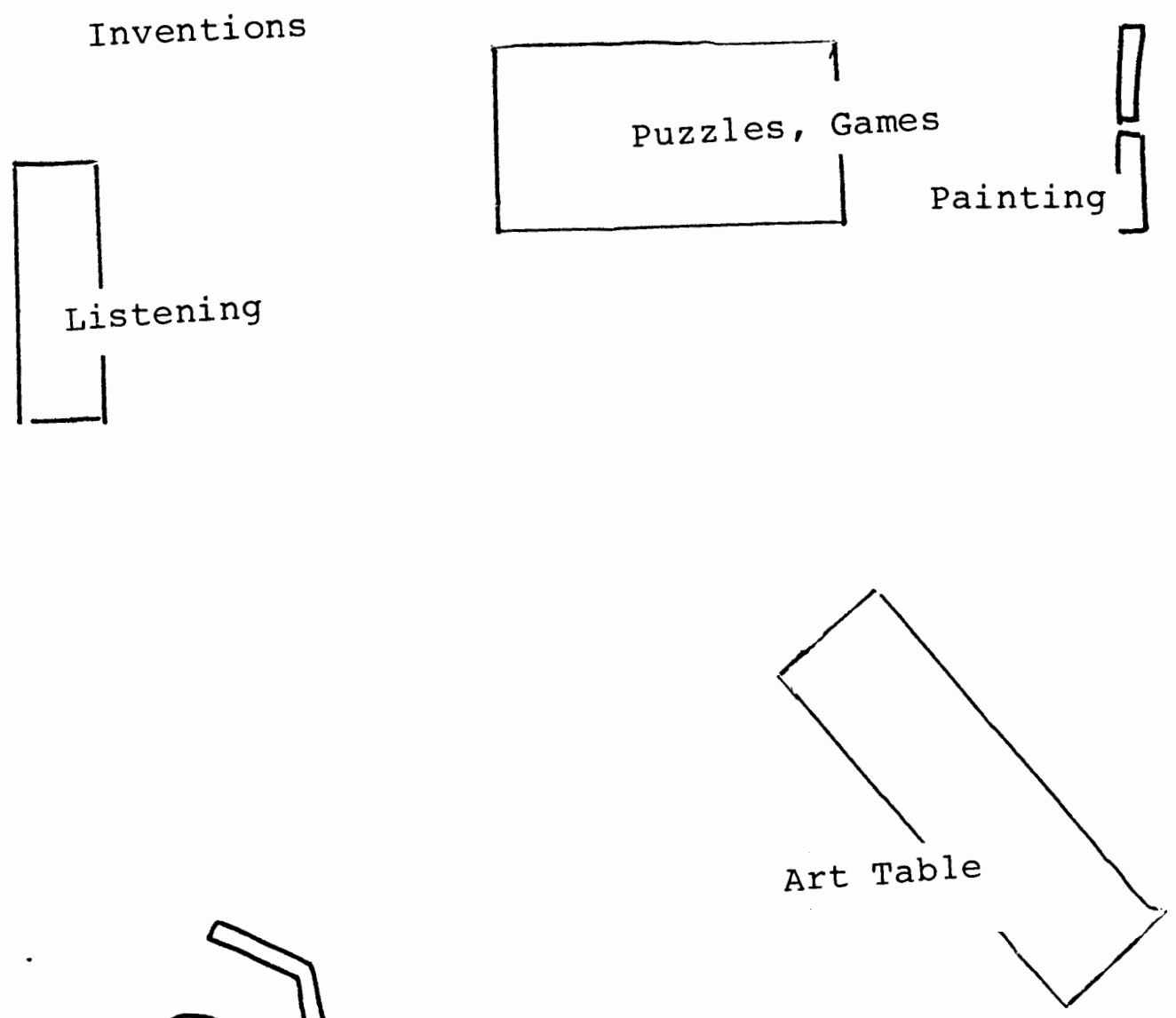

Block Area

Dramatic Play (The Play House)

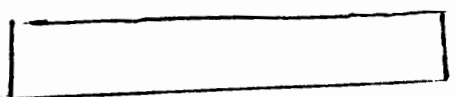

